\title{
HOW CAN SWEDEN DEAL WITH FOREST MANAGEMENT AND MUNICIPAL PLANNING IN THE SYSTEM OF ONGOING LAND-USE AND MULTILEVEL PLANNING?
}

\author{
Olof Stjernström ${ }^{1}$, Örjan Pettersson ${ }^{2}$, Svante Karlsson ${ }^{3}$
}

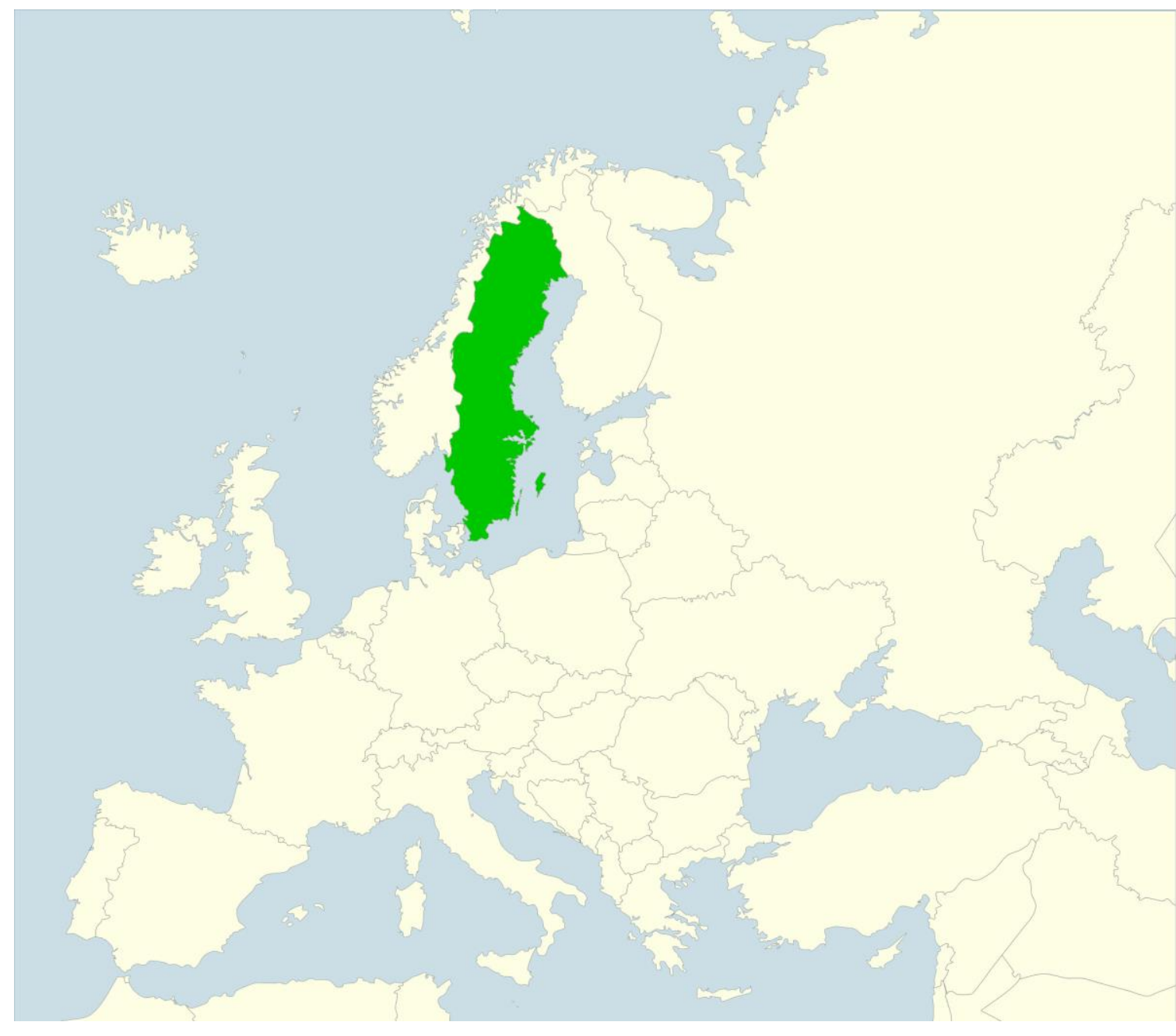

\footnotetext{
${ }^{1}$ Olof Stjernström, Department of Geography and Economic History, Umeå University, Samhällsvetarhuset, SE-901 87 Umeå, Sweden and Faculty of Social Sciences, Nord University, Kongens Gate 42, 7713 Steinkjer, Norway; e-mail: olof.a.stjernstrom@nord.se

2 Örjan Pettersson, Department of Geography and Economic History, Umeå University, Samhällsvetarhuset, SE-901 87 Umeå, Sweden; e-mail: orjan.pettersson@umu.se

${ }^{3}$ Svante Karlsson, Department of Geography and Economic History, Umeå University, Samhällsvetarhuset, SE-901 87 Umeå, Sweden and Department of Geography, Media \& Communication. Karlstad University, Universitetsgatan 2 , 65188 Karlstad, Sweden; e-mail: svante.karlsson@kau.se
} 
Abstract: This article studies the relation between territorial and functional planning by investigating the Swedish local comprehensive planning system and the forest management. The former is locally based and the latter is functionally based or sectororientated. By interviewing planners from the County Administrative Boards responsible for monitoring the national interests in the Swedish municipalities and forest managers from the Regional Forest Agency Administration, we found out that forest- and municipality related issues that coincide or interact with each other is normally considered in the collaborative planning process based on consultations and cooperation between the involved stakeholders. Weaknesses in the collaborative planning system consists of lack of coordination between the involved legal frameworks as well as lack of local planning resources and in some cases competences.

Key words: Municipal planning, forest management, collaborative planning, multilevel governance

\section{Introduction}

During recent years, a number of events and incidents have been observed and discussed in the Swedish media, where different interests or claims on the forest land has been in essence of the discussions (Zaremba 2012, Stjernström et al 2013). The issue has quite often been related to forests owners that made thinning and/or final felling legitimized by the Forestry Act in urban fringe forests or other popular forests. The municipalities, which in Sweden have a social and spatial planning monopoly, have been out of any authority in those occasions since the forest land and forestry, formally regarded as ongoing land-use (Stjernström et al 2013) and therefore is an exception from the municipal physical planning (Stjernström et al 2017). On the other hand, according to present legislation, the forest owner always has the right to implement forest related management issues and other land-use activities related to forestry without any interference from the municipality. These circumstances are normally and have historically not been a problem. The forest owners have maintained their forests and the municipalities have a responsibility for social and physical planning within their territories. In case of any emerging conflicts or problems, this has been resolved by consultation and agreements. However, there still exist a structural conflict in the planning system since there are different legal frameworks regulating forests and forestry on the one hand and municipal planning on the other hand (Sandström et al 2012, Stjernström et al 2013, Stjernström et al 2017, Elbakidze et al 2012, Andersson et al 2013). Furthermore, it is reasonable to include an increasing awareness among the general public concerning environmental issues in general and forest related issues in particular (Eriksson et al 2012a, Eriksson et al 2012b). The undisputed position of the forest owners and the forest industry has recently been challenged by the sustainable development, new planning demands and a multifaceted land-use (Ambjörnsson Laszlo et al 2016). The focus in this article is the relation between forestry and municipal planning in Sweden.

The multi-level planning (Keskitalo 2004, Keskitalo et al 2014) authority and legal frameworks in the Swedish case refers to the local self-determination with the municipality in charge of the formal land-use planning mainly manifested by the local comprehensive plans. The general and national interests are communicated with the regional state organisation, County Administrative Board. As concerns the forest landscape that refers to the Forestry Act (SFS 1979:429) which are vaguely related to the land-use legal framework as expressed in Environmental Code (SFS 1998:808) and the Planning and Building Act (SFS 2010:900). The Swedish Forest administration is governed by the Swedish Forest Agency with their regional offices in charge of the regional and local responsibilities. This result is an overlapping or multilevel governance of the land-use planning (Blücher 2013, Engström \& Cars 2013, Stjernström et al 2013). Other examples of this is landuse related to minerals and mines. However, this study focuses on the relation between municipal comprehensive planning and forest land authority and planning. 
Sweden is a forested country. About two-third of the total land area or 28 million hectares is covered with forests (Skogssverige 2017). Most of the forest is spruce and pine. 330,000 private forest owners privately own about $50 \%$ of the forestland, forest companies own another $25 \%$, $15 \%$ by the Swedish state and the rest is owned by forest commons, the church and other institutions (ibid 2017). The Forestry Act includes two equally important goals - the production target and the environmental target. The annual growth of forest is generally higher than the felling, which contributes to a sustainable forestry.

A Swedish Forest Management Plan relates to the individual forest property owner. The plan used to be mandatory but today it is voluntarily. For certified forest properties, a management plan is necessary. The plan is an inventory of the forest on the property, like age, distribution of tree species, soil conditions, growth, protection etc. The plan shows the immediate needs of forest activities as well as suggestions for the future. The plan also considers the environment and if some of the forest area need more environmental concern (Swedish Forest Agency 2016). These forest management plans are by no means comparable with a Swedish municipal plan. However, an individual forest management plan is a part of a much wider system under the national Forestry Act and to some extent guided and monitored by the regional offices of the Forest Agency.

The municipal comprehensive plans are under the umbrella of the Planning- and Building Act. The focus in this study is to investigate how a resource, as in this case, the forests, are considered in the spatial planning system and how the different legal aspects and instruments of forestry management planning and municipal planning relate to each other at the local level (municipalities). We will furthermore scrutinize the status on the identified national land-use interests and how they are or are not considered in the local spatial planning. The guiding question is how forestry as a land-use activity manages to maintain their relatively independent role in relation to the local spatial planning in general.

Through interviews with officials representing both sides (municipal spatial planning and forest planning), this study aims to assess why forestry planning is not fully integrated into the municipal spatial planning or vice versa, and to discuss the relations of these simultaneous and contradictory uses in the context of collaborative planning. From the aim, the following specific research questions were derived, all of which are explored in terms of the current situation:

1. What circumstances have contributed to the comparatively independent legal framework for and practice of forestry in Sweden?

2. How does the collaborative planning and cooperation between the local territorial planning and the sector forest interest works in practice?

3. How could a multilevel planning system cope with a sector interest such as the forest interest?

\section{Previous research}

The economic and administrative power in forest use and forest economy is most often located outside the region and based on a national strategy rather than a regionally-based one. Gunton (2003) relates to the dependency theory and the staple theory as developed by Innis (1956) and Mackintosh (1964). According to Gunton (2003), it is sometimes debated whether natural resources contribute to a regional development or if natural resources impede the regional prosperities. The former relates to the idea of comparative advantages as presented in, e.g., Myrdal (1957), whereas the latter refers to the dependency school.

According to Lawrence (2009), the forest-related professions and expertise also tend to maintain this centralized position. These circumstances contribute to a certain path dependency relation in the forest policy. The national interest and the overarching target to maintain sustainable growth in the forests to supply the industry with forest resources still overshadows other interests such as regional-based production, tourism, recreation, etc.

In Sweden, as well as in many other countries, the forest management planning has a rather weak or limited relation to the general municipal planning. However, this varies between the countries and between main types of owners (Cullotta et al 2015). Many countries have 
national forest programmes, whereas several also have programmes on regional and even local levels (Tittler et al 2001, Gislerud \& Neven 2002, Ananda 2004, Leskinen 2004, Montiela \& Galiana 2005, Cullotta \& Maetzke 2009, Weber 2017). In these strategic documents, objectives and guidelines for multiple-use and sustainable forest management are presented. From a Swedish perspective, the neighboring country Finland is of particular relevance due to similar conditions in terms of boreal forests, a large forestry sector, many small private forest owners, Right of Public Access etc. For about two decades, Finland has developed regional forest programmes (Leskinen 2004, Kangas et al 2010, Saarikoski 2012, Finlands Skogscentral 2016, Tikkanen 2017). The regional forestry centers produce, in collaboration with numerous actors within their territory, Regional Forest Programmes for a forthcoming five-year period. In these documents, the current situation regarding forest land-use and forestry related activities are described, as well as how the region can contribute to the objectives outlined in the national forest programme. The regional programmes also contribute with input to the national programme. Even though the regional programmes are strategic, rather than spatial, and focus on forest land-use and forestry, there is an ambition to connect forest related issues with spatial planning in general, not least on a regional level, which in Finland has great importance for land use planning on local/municipal level.

The Swedish model with forest management planning separated from general municipal planning is discussed in Andersson et al (2013), in which the authors argue for a broader landscape approach including not only forestry land-use but also the importance of green infrastructure demands.

The importance of spatial planning and a possible emerging conflict in land-use in the forest land have been emphasized by Andersson et al (2013). They investigated the land-use interest of the forest industry and the societal interest of maintaining and developing a green infrastructure. The study reveals that the spatial variation among the Swedish municipalities are rather large both in terms of policy needs and opportunities for rational forestry as well as green infrastructures (Andersson et al 2013). The study also concluded that there is a need of new modes of cooperation and "integrated spatial analysis" to bring different stakeholders together (ibid 2013). Several studies have shown similar results, however they also discuss the importance of stakeholder incentives and legal frameworks that enable or force collaborative planning based on consultation, cooperation and a more integrated planning system (Folke et al 2005, Andersson et al 2013).

The importance of a collaborative planning approach to bring different stakeholders together with the forest landscape in focus is often emphasized (Angelstam et al 2011. Andersson et al 2013, Elbakidze et al 2012). A key aspect in spatial planning is also property rights; however, this is not to the same extent discussed in the referenced literature as the need of collaborative planning approach. To use the principal of sustainable development in planning and planning related activities seem to be a common approach in the theoretical and practical suggestions of collaborative planning in the forest landscape (IMFN 2008). The forest is merely considered in terms of a landscape rather than a socio-economic space. In Fries et al (1998) different approaches to forest landscape planning is discussed. The socio-economic indicator in this study is the forest production. Collaborative planning in terms of working with the participants or the actors and not against have some similarities with the ideas of coproduction developed by Albrects (2013). Planning and developing a common good in relation to its users implies a planning process on more equal terms and in relation to natural resources including individuals depending on the resource in learning planning system (Gardner et al 1990, Albrects 2013). Collaborative planning has been successfully applied in for instance, in questions concerning land-use and indigenous populations (Cullen et al 2010, Sandström 2012).

Local and regional spatial planning develops in a direction that might complicate the collaborative ideas in relation to the forest resource and forest management. Friedmann \& Weaver (1979) mark the point of departure in understanding the importance of a holistic spatial planning in order to deal, among many other issues, with the socioeconomic disparities (Galland 2012a, 2012b). Galland (2012), Albrects (2013) and Olesen (2013) also argue that the holistic welfare orientated regional planning in recent years has been replaced by a regional planning characterized by a planning for regional growth (see also Baldersheim \& Ståhlberg 2002). New forms of policies 
and spatial organizations have also contributed to a development of agendas and areas of responsibilities that has to be filled in. Galland (2012b) refers to soft spaces in the sense of planning at a regional level with a somewhat unclear spatial structure of power (Haughton et al 2009). The economic and social interest in the Swedish forest landscape could arguably be understood as a domain of intervening "filling in" interests, since a holistic planning approach is missing. The more project oriented public planning process partly sets formal planning aside. Hybrid planning (Galland \& Hansen 2012) brings along questions about the public interests in the planning process and questions of favored groups in the planning process (ibid 2012). Ideas of participation in planning issues related to governance are not without problems. Interest groups, stakeholders and the public are represented in different ways depending on the object of the planning process.

\section{Method and delimitations}

The methodological approach is based on two pillars. The first pillar is a document analyzes, analyzing the legal framework of planning in Swedish municipalities and the legal framework for forestry and how they relate to each other. The empirical material comprises law texts, statutes related to forestry and planning, legislative history up to the present legal framework, comprehensive municipal plans, and public Swedish Government Official Reports. The second pillar is based on semi-structured interviews with state officials at the County Administrative Boards and at regional Forest Agency offices. The county administration mainly has an advisory function in the Swedish planning system, but in certain more specific situations, they also scrutinize the municipal plans. In this way, the County Administrative Boards have substantial knowledge of the local conditions and a broad overview regarding the local planning situation in their own county. The officials have frequent contacts in their counselling and controlling role with not only the planners at the municipality level but also advisory contacts with sector interests such as forest planners at the regional offices of the Swedish Forest Agency. Officials from the Forest Agency regional offices related to the same counties were also interviewed. Local municipal planners were not included in the study. The arguments for this are the central intermediate position of the planners at the County Administrative Boards. They have regular consultations with the local municipalities and exercise to some extent a controlling function in relation to the local planning. The planners at the county administration are also obliged to send the local comprehensive plans for consideration to other sector interests such as the regional Forest Agency's offices. The County officials and the Forest Agency's officials were contacted by e-mail and thereafter by phone. The interview took place some days after the phone call. A total of sixteen semi-structured interviews were conducted, of which fifteen were held over the telephone and one as a face-to-face interview. The interviews lasted 30 minutes to an hour. Seven of the 21 county administrations in Sweden took part in the study; Gävleborg, Jämtland, Norrbotten, Södermanland, Värmland, Västerbotten and Örebro. Most of these are forest counties in the northern half of Sweden and priority was thus given to counties where forestry is considered as being of relatively great importance. This was partly balanced with two counties in the southern part of Sweden (Örebro and Södermanland counties) with more mixed land-use and where agriculture and built-up/metropolitan areas is more pronounced, yet with quite extensive forest areas in many parts. In the same counties, officials from the regional offices of the Forest Agency were interviewed.

The semi-structured interview guide used in the interviews comprised questions that were more specific, with a few open-ended questions. The questions focused on topics such as the municipals planning efforts, the relation between municipal planning and forest planning and the county administrations view on forest planning and the Forest Agency officials view on municipal planning and their respectively view on the consultation process and the multi-level planning approach. The interview material has been analyzed thematically deriving from five major topics; path dependencies, collaboration, municipal planning competence, resources and multilevel planning. These are largely in accordance with the research questions and the concepts and circumstances frequently mentioned in the interviews (Braun \& Clarke 2006). 


\section{Results}

\subsection{Forestry and forest land in legislation and planning}

Both document studies and interviews confirmed that the Swedish "municipal planning monopoly" is a truth with some modifications. Forests and forestry are examples of cases in which the municipalities lack a clear mandate in relation to how the resources in the forest landscape are planned and used (Berge \& Adolfson 2011).

The forest land and forestry are nevertheless also key factors in understanding the evolution of the physical planning in Sweden. The present Forestry Act (SFS 1979:429) clearly states the need for balance between the production target and the environmental target. This important principle was established in the 1993 revised Forestry Act (ibid). The two targets put together conflict somewhat with each other. The relationship between the Environmental Code (SFS 1998:808) and the Forestry Act (SFS 1979:429) is weak. The Environmental Code states that "forest land of importance for forestry should, as far as possible, be protected against acts that markedly damage its rational use for forestry" (SFS 1998:808 ch. 3, s 4, EC).

The Environmental Code also contains the concept of "ongoing land-use", which was and still is an innovative way of maintaining an important land-use interest. Ongoing land-use is not to be affected by other interests, such as various national interests. It also has the consequence that the fundamental land-use regulations are not applicable in relation to changes in land use that connects to forestry and forest production such as clear cuttings, soil scarification, choice of wood species, etc. It is only when it comes to water issues like ditches, the draining of wetlands, etc, and the protection of some deciduous forests (oak- and beech forests etc) that the land-use changes have to be approved in relation to the Environmental Code. The concept of ongoing land-use is also fundamental for the practice and understanding of major land-use interests.

To understand the present relation between spatial municipal planning on the one hand and the forest land-use interest on the other, the establishment of the current physical planning has to be considered. Already in the mid-1960s, the Swedish state department of internal affairs initiated an investigation of the future need for physical planning and the spatial order and priorities in physical planning. This should be seen in the light of an emerging environmental consciousness and an increasing awareness of the country's limited resources. The efforts resulted in two major Governmental Official Reports (Planning with scarce land- and water resources/SOU 1971:75 and SOU 1979:54).

These reports introduced many of the present fundaments for physical planning. The intention was to clarify the distribution of responsibilities between the central and the local level (the municipalities). An innovative solution was to reinforce some of the public interests and label them national interests, meaning that these interests should be considered in local planning but monitored and scrutinized by the state via the County Administrative Board. Furthermore, forestry and agriculturally related issues had a unique position in the early Government Official Reports from the 1960s and 1970s as well as in the legislative history. This unique position remains, for example in the special treatment of forestry and agriculture as not being "national interests" but instead so-called "economic sectors of national importance" (SFS 1998:808, Ch. 3, s 4, EC). The reason why forest and agricultural land still have this unique position relates to the central, governmental ambitions to reinforce the municipal rights of self-determination in relation to physical planning. In the opinions of the parliament's committees for trade and business, housing and agriculture two lines of argumentations can be identified in the treatment of the suggested new Planning and Building Act (Riksdagen, The housing committees' opinion to a new Planning and Building Act, 1986/87:1); the planning argument and the resource argument, respectively. The former departs from the municipal rights of self-determination and argues that if the forestland also should be considered as a national interest, the state influence in the municipal selfdetermination rights would be too strong and cover very big areas.

The resource argument was promoted by the committees of Trade and Business and Agriculture who both argued that the provision of timber was important and might be endangered if the power was handed out to the municipalities. This might be understood from the central governments ambition to maintain a certain degree of national self-sufficiency important/strategic resources 
due to the experiences of World War II and the Cold War period thereafter. The committees also argued strongly that the concept of ongoing land-use was necessary in order to sustain a largescale forestry and forest industries. This idea was later accepted by the Parliament. The committees were also negative to the suggestion of declaring forestlands as national interests but at the same time, they expressed a concern for the status of the forestland in relation to other kinds of national interests. Therefore, they suggested a supplementary addition to the proposed bill. The addition, was that forestry and the agricultural sector should be considered as "economic sectors of national importance" (contrasting the "national interests") and have the same status as "national interests". It is a semantic question to understand the theoretical difference between national interests and economic sectors of national importance, but the concept of ongoing land-use is essential for the latter. The main difference was and still is, that national interests was (and still is) under the umbrella of the County Administrative Boards. By not declaring forests and forestry as a national interest, the forest interests and the Forest Agency could maintain their responsibility and influence as a strong sector interest in the national planning system. The municipalities were left behind. Even though, the implementation of the new Planning and Building Act gave the Swedish municipalities increased rights of self-determination regarding land-use planning, the forest lands and forestry as well as agriculture were basically left outside the local planning domains.

\subsection{Multilevel planning issues}

A repeatedly common opinion among representatives in Swedish planning is the lack of regional planning (Johnson 2013, Nyström \& Tonell 2012). The function of the County Administrative Boards can to some extent be understood as a regional actor with regional functions in planning, but just with the main task of considering national (state) interests in the municipalities. However, despite the legal framework, there are substantial disparities in quality and ambition between the municipalities' comprehensive plans, which clearly affect the possibilities of regional coordination. One respondent claimed that:

"However, there prevails a certain degree of over-confidence about the Planning and Building Act and the capability of the comprehensive plans to deal with broad-brush issues". (CAB $\left.{ }^{4}\right)$

About half of the respondents from the County Administrative Boards pointed out the absence of visible links between the mandatory comprehensive municipal plans on the one hand and the regional level on the other. The vague legal framework and the legitimacy of the different plans form a central issue in this matter, as does the increasing sectorization, with several state bodies involved. All respondents' argued that the cooperation and consultation between the regional offices of the Forest Agency and the County Administrations Boards works well. Some of the County Administration Board's supervision regarding municipal planning also relates to the forest landscape. Most of the respondents agree that closer cooperation or a regional coordination of the two organizations is preferable. A merging of the two organizations was also discussed in an official investigation during 2012 (SOU 2012:81). One of the respondents argued that the forestland is to a high degree planned from a natural resource perspective with a clear forestry sector interest, which negatively affects the relation to other planning issues in the forest landscape. Among the respondents representing the Forest Agency, no one mentioned a merge of the two organizations as an option. Quite the opposite the Forest Agency respondents expressed satisfaction with the present cooperation with the county administrations.

\subsection{Forests and the local planning monopoly}

As mentioned earlier, the municipal planning monopoly has a strong position in Sweden and allows the local authority to decide how land and water areas should be planned and used. Areas considered being of national interest, as well as some sectorial interests, partly represent an exception to this. The municipalities have an obligation to consider these national interests in their plans, and to state how these interests should be secured.

\footnotetext{
${ }^{4} \mathrm{CAB}$ refers to representative(s) from one of the County Administrative Boards, RFA refers to representatives from one of the regional offices of the Forest Agency.
} 
The productive forestland is normally not a national interest (unless it is classified as a national interest according to nature preservation, outdoor recreation, reindeer herding, etc.). The productive forestland represents an economic sector of national importance, which, according to the Environmental Code and the Planning and Building Act, must not be aggravated by other interests. All respondents argue that this is somewhat problematic from a planning perspective. At first glance, the problem seems semantic; however, national interests has to be considered in the municipal plans and approved by the County Administrative Boards, whereas forests and forestry comprise a sector interest of great importance but without having the status of "national interest". This results in a rather weak relation to municipal planning. It would not be sustainable, however, to transform the productive forestland into an area of national interest, as this would probably result in an extremely weakened national interest. On the other hand, the County Administrative Board has no legal instrument for dealing with insufficient land use and planning on forestland. As a result,

"The municipalities lack incitement to plan for the productive forest land despite the fact that the Planning and Building Act states that a comprehensive municipal plan should comprise the whole territory". (CAB)

About half of the respondents from the County Administrative Boards are of the opinion that forests are considered rather briefly, or not at all, in the comprehensive plans.

"The forest land is normally a terra incognito or a white spot on the map, and lacks references in the text."(CAB)

However, in some cases the forestland is elaborated on more in the plans, especially the urban fringe forests, which are attracting increasing attention in relation to the importance of access to areas of importance for outdoor recreation. On the other hand, it could be argued that many municipalities has a lack of resources and competence in relation to forestry planning. Respondents from both organizations often mention this circumstance. In particular, smaller municipalities with large areas of forestland have limited planning capabilities (see also Bjärstig 2018).

\subsection{Forest management and comprehensive municipal planning processes}

One of the problems mentioned by three of the respondents is that the County Administrative Board lacks an instrument for the planning of forest and agricultural lands. This is perhaps even more obvious in the municipalities' land claims of agricultural land for urban growth. As long as these areas are not classified as national interests, the County Administrative Board has limited possibilities to affect the municipal planning.

"From a theoretical point of view the instrument of defining important areas as national interests could be applied; however, there is a risk of misuse of the concept of national interest and its central values" (CAB)

One of the respondents goes even further, arguing that:

"The government or the central state level has always cared for the important nature-based resources and has never handed over the control of these essential resources to other levels of planning authorities" (RFA)

There are many reasons for this. The implementation of "national interests" was partly a strategy for dealing with this and still keeping the municipal planning monopoly. National interests instrument allows the central level to have some control regarding common pool resources and yet let the municipalities be the main actor in the overall planning process. However, since forestry is not a national interest, the County Administrative Board lacks the legal instruments to advice and monitor the municipalities' comprehensive plans concerning this aspect. 
Many of those interviewed express that the recent development, whereby the social values of the forests in general and urban fringe forests in particular have been emphasized, has contributed to the upgrading of forests in the planning process. This is particularly important for the forests' social values in a local context as important areas for the growing urban population and its demand for nature-based recreation and proximity to forest landscapes. In this context, many of the respondents are of the opinion that the national interest instrument is a bit blunt and partly overlaps national interests for areas of importance for outdoor recreation. The whole idea is that areas of national interest relate to areas of interest for the country as a whole. That a forest is designated an urban fringe forest does not necessarily mean that the area has unique and valuable qualities in a national context, but quite often the opposite; i.e., an ordinary forest that does not meet the criteria for national interests could yet have major importance for the neighboring urban population. Not least, the importance of social values has in many cases resulted in a much closer cooperation between the regional offices of the Forest Agency and the municipalities.

\subsection{Potential problems and possible solutions}

A majority of the respondents express the difficulties in managing the forests and forestry in the municipal planning process. Most of them also mention the changed view on forests in society, and that the local dimensions of forest issues have increased. One expression of this is the discussion of the importance of urban fringe forests and the production of ecological services, which offer areas for recreation, biodiversity, etc. In the interviews, two possible development courses crystallize. One suggested alternative is to strengthen the municipal planning and give the municipalities a mandate to consider the forestland in general, and in the comprehensive planning in particular. The other alternative suggested by some of the respondents is to strengthen the local competence in the present forest-related planning by increasing the cooperation between the regional Forest Agencies and the municipalities.

One of the issues brought up by the respondents is that forestland and forestry are not part of the basic data in the comprehensive planning process, and are furthermore not examined by the County Administrative Board. A weakness of the present framework is the concept of "ongoing land-use". Traditional forestry focused on timber production is an ongoing land use that limits the possibility to influence forestry as such and plan for other activities in the forest landscape.

"The concept of ongoing land-use needs to be better analyzed. Municipalities and County Administrative Boards can hardly influence the planning of the forest landscape scenery where forestry plays a major role" (RFA)

An alternative approach suggested by two of the respondents is a "boosted" regional planning. Since the regional level in the Swedish context is rather weak, this approach relates to increasing self-determination on the regional level in order to legitimize regional planning. However, it should be stressed that the embryonic steps taken thus far to develop the regional level in Sweden are

"rather an expression of strong central state sector interests in maintaining and keeping together the spatial planning (of the sector interest) and making use of existing resources in an economically sustainable way in a regional context." (CAB)

Nevertheless, some of the respondents spontaneously mention that the central problem does not necessarily only relate to the organizational question. Instead, they express that planning competence is lacking in many municipalities (especially in smaller ones), which makes it necessary for the County Administrative Boards to intervene to adjust and guide the local planning efforts. It was also suggested that more municipalities should cooperate and, for example, produce mutual basic planning material in a comprehensive planning process. Some respondents suggest that especially smaller municipalities should preferably increase their cooperation with neighboring municipalities, and elaborate partly or mutually comprehensive plans: 
"In some planning issues of a more encompassing nature, the present administrative organization seems to be somewhat outdated" (CAB).

More cooperation between municipalities in planning issues has a double advantage. Partly, it increases the access of competence in planning by increasing the number of planners in various fields from more than one municipality; and partly because of a better regional overview in physical planning issues such green infrastructure, transportation infrastructure, service provision, etc. This is especially relevant in rural areas with few inhabitants and vast forest areas. Some of the respondents go even further: This implies an acute necessity for high-quality comprehensive municipal planning.

"The instrument is present but the comprehensive municipal planning has developed into a chimaera. The comprehensive plans have developed into something that only relates to the population centers. We would also need more elaborated comprehensive plans that clearly relate to the natural resources in the municipalities" (RFA).

Another issue brought up by the respondents is the importance of future visions in the comprehensive plan. The visionary part is quite often vague and needs to be developed. In too many municipalities, the comprehensive plan is neither up-to-date nor of any strategic importance.

\section{Discussion}

Forest management and municipal planning in the Swedish context is hard to compare. They constitute two separate legal systems and two separate practices. The meaning of "local" has a different connotation in forest planning compared to municipal planning. Whereas forest planning in Sweden mainly relates to the individual owner's planning and forest practices (felling, thinning, diching, planting etc), municipal planning relates to the local level of planning in the national planning system. This difference in the understanding of the concepts of forest- and municipal planning respectively contributes to the confusion in the relation between forest management and municipal planning.

The path-dependency relations are important to understand the development of managing natural resources. Another related aspect illustrates the struggle between territory and function, as initially discussed by Friedmann and Weaver (1979). Forest land has long been an essential resource for the forestry sector, and as such has played an essential role in the Swedish economy. This is probably a central explanation for the strong sector interest. In Sweden, forests relate mainly to the economic sector rather than local planning ambitions (Berge \& Adolfson 2011, Andersson et al 2013, Bjärstig et al 2018).

The Swedish municipalities (i.e. the local level territorial planning), lack an instrument for considering and including the forests as a resource in municipal planning. Part of the problem relates to the concept of "ongoing land-use" and how the implications and interpretations of that concept. For example, should forestry always be regarded as "ongoing land-use" in relation to the implementation of new technology, new forest management and the development of monocultivation of the forest landscape? Forests attract other interests and provide other functions than solely timber production; therefore, a planning process that considers more interests and potential conflicts could be discussed. Is the forest land supposed to be used in the same way everywhere, or should local conditions and local planning be able to see forests as resources in a local development process? The latter is an argument for a clearer role of forest issues in the municipal planning process and a more developed dialogue between the municipalities, forest property owners and the Forest Agency. Even though there has been some criticism in Finland, for instance, regarding participation in regional forest programmes (Saarikoski 2012, Tikkanen 2017), we believe that the Finnish experiences could be worth considering in Sweden as well. In particular since it offers an intermediate level and communicative instrument to connect multipleuse forest issues with spatial planning on regional and local levels, not least municipal comprehensive planning. Currently, a national forest programme is being prepared in Sweden (Johansson 2016). 
The strong sector interest manifests the centralized power over important natural resources and has an agenda partly based on its own logic rather than a logic that goes along with the general social and economic development. The arguments to the division between municipal planning and forestry planning put forward in the initial preparations to the present planning legislation and the evaluations made by the various parliament committees before the decision in the parliament illustrates two rather clear discourses.

The planning discourse relates to the rather long historical tradition of municipal selfdetermination in Sweden. The initiative to a reformed planning legislation was partly based on the idea of reinforcing the municipal self-determination, in particular in relation to physical planning and land-use. To some extent, this new legislation marked a shift in the national view on important natural resources. The idea to strengthen the local political power was ambiguous. In order to maintain the central or national control, the concept of national interests were introduced with the County Administrative Boards as the intermediator between local/municipal interests and the national interests. The advocates for this change also argued that a national interest status on the forestland would result in a very extensive national influence in local planning. In the aftermath of this discussion, this seems a bit paradoxical since the forest land and the forestry activities remained in a central state agency with weak connections to municipal planning.

The industrial discourse relates to the strong influence of existing economic and administrative structures manifested by the property rights, the forest industry, the Swedish Forest Agency and the farmers' organization. In the parliament committees representing these interests, foremost, the committee for trade and industry, and the agricultural committee, were concerned about the supply of raw material (timber) to the forest industries (mainly sawmills and pulp and paper mills) and the ongoing land-use in the forests. The latter partly relates to the change of the legislation concerning compensation. The question was at that time whether a landowner should be compensated or not if the current land-use were restricted and challenged by other land-use interests. The answer became an emphasis on the concept of ongoing land-use, which left the forestry sector untouched and outside the jurisdiction of municipal planning.

\section{Conclusions}

The separate legal frameworks for public planning and forest management respectively complicate the local land-use planning. In addition to this, the rather poor connection between the Swedish Forestry Act (SFS 1979:479) and the Environmental Code (SFS 1998:808) also is an aggravating circumstance. This was also emphasized by some of the interviewed representing the County Administrative Boards. The concept of ongoing land-use is essential in understanding and manifesting the forest land-use interest. Forestry is in the normal case to regard as an ongoing land-use, which is supposed not to be affected by competing interests. On the other hand, the custom of the Right of Public Access is regarded as an important tool to consider the public interest as well. This is well established and supported by most of the interviewed from both the County Administrative Boards and the regional offices of the Forest Agency. In addition, the path dependency and the strong economic forest interest are important explanations to the strong forest sector interest and the lack of forest related issues in local comprehensive planning, which for instance can be related to arguments by Innis (1956) and Lawrence (2009).

The collaborative planning approach (Andersson et al 2013) as well as the multi-level governance approach (Keskitalo et al 2014) offers a tool to overcome the difficulties. The rather well established consultation process on the first hand between the County Administrative Board and the regional offices of the Forest Agency, and on the other hand between the municipalities and the above-mentioned state agencies. The consultation process solves most of the problematic issues according to the interviewed. This means that within the system of sector interests in territorial planning, conflicting issues are normally dealt with in the consultation process. Nevertheless, a stronger link between legal framework and between sector interests and municipal planning would simplify the planning process and stimulate local engagement. The collaborative approach as well as the consultation process does not only illustrate the importance of communication between different formal stakeholders in the formal planning process, but also the importance of capacity building and competence sharing. A major obstacle 
for an improved planning process with a comprehensive approach at the local level is many times the lack of resources and competences (Bjärstig et al 2018). This is evident in the case of the northern periphery in Sweden with geographically large municipalities with small populations. The Swedish example calls for a better coordination and collaboration in the municipal planning process. Balancing the territorial municipal planning interest against expert forest knowledge practices illustrates the importance of an open collaborative planning process. A further development of the collaboration between the Swedish Forest Agency on the one hand and the municipal planning and the monitoring function of the County Administrative Boards on the other hand, goes well in line with the Swedish multilevel governance approach. Finally, regional forest programmes, as implemented in many other countries (Tittler et al 2001, Montiela \& Galiana 2005, Kangas et al 2010 , etc) could potentially also enhance participation and collaboration on forest issues between actors at local and regional levels in Sweden.

Academic references

[1] Albrechts, L. (2013). Reframing strategic spatial planning by using a coproduction perspective. Planning Theory 12(1), 46-63. DOI: 10.1177/1473095212452722.

[2] Ananda, J. (2004). Implementing participatory approaches in formulating regional forest policy. International Journal of Sustainable Development 7(4), 398-409. DOI: 10.1504/IJSD.2004.006415.

[3] Andersson, K., Angelstam, P., Elbakidze, M., Axelsson, R. \& Degerman, E. (2013). Green infrastructures and intensive forestry: Need and opportunity for spatial planning in a Swedish rural-urban gradient. Scandinavian Journal of Forest Research 28(2), 143-165. DOI: 10.1080/02827581.2012.723740.

[4] Angelstam, P., Axelsson, R., Elbakidze, M., Laestadius, L., Lazdinis, M., Nordberg, M., Pătru-Stupariu, I. \& Smith, M. (2011). Knowledge production and learning for sustainable forest management on the ground: Pan-European landscapes as a time machine. Forestry 84(5), 581-596. DOI: 10.1093/forestry/cpr048.

[5] Ambjörnsson Laszlo, E., Keskitalo, E. C. H., Karlsson, S. (2016). Forest discourses and the role of planning-related perspectives: the case of Sweden. Scandinavian Journal of Forest Research, Vol. 31. Issue 1, 111-118. DOI: 10.1080/02827581.2015.1070197.

[6] Baldersheim, H. \& Ståhlberg, K. (2002). From guided democracy to multi-level governance: Trends in central-local relations in the Nordic countries. Local Government Studies 28(3), 74-90. DOI: 10.1080/714004149.

[7] Berge, B. \& Adolfson, B. (2011). Effektiva planeringsprocesser i - strategier för ytstora kommuner med liten befolkning [Slutrapport pilotprojekt]. Umeå/Luleå: Länsstyrelserna I Norrbotten och Västerbotten.

[8] Bjärstig, T., Thellbro, C., Stjernström, O., Svensson, J., Sandström, C., Sandström, P. \& Zachrisson, A. (2018). Between protocol and reality - Swedish municipal comprehensive planning. European Planning Studies, 26(1), 35-54. DOI: 10.1080/09654313.2017.1365819.

[9] Blücher, G. (2013). Planning Legislation in Sweden - a history of Power over Land-use. In Planning in Sweden (pp. 47-57). Stockholm: Swedish Society for Town and Country Planning.

[10] Braun, V. \& Clarke, V. (2006). Using thematic analysis in psychology. Qualitative Research in Psychology 3(2), 77-101.DOI: 10.1191/1478088706qp063oa.

[11] Cullen, D., McGee, G. J., Gunton, T. I. \& Day, J. C. (2010). Collaborative planning in complex stakeholder environments: An evaluation of a two-tiered collaborative planning model. Society and Natural Resources 23(4), 332-350. DOI 10.1080/08941920903002552. 
[12] Cullotta, S. \& Maetzke, F. (2009). Forest management planning at different geographic levels in Italy: hierarchy, current tools and ongoing development. International Forestry Review 11(4), 475-489. DOI: 10.1505/ifor.11.4.475.

[13] Cullotta, S., Bončina, A., Carvalho-Ribeiro, S. M., Chauvin, C., Farcy, C., Kurttila, M. \& Maetzke, F. G. (2015). Forest planning across Europe: the spatial scale, tools, and intersectoral integration in land-use planning. Journal of Environmental Planning and Management 58(8), 1384-1411. DOI: 10.1080/09640568.2014.927754.

[14] Elbakidze, M., Angelstam, P. \& Axelsson, R. (2012). Stakeholder identification and analysis for adaptive governance in the Kovdozersky Model Forest, Russian Federation. The Forestry Chronicle 88(3), 298-305.

[15] Engström, C-J. \& Cars, G. (2013). Planning in a New Reality - New Conditions, Demands, and Discourses. In Planning in Sweden (pp. 11-21). Stockholm: Swedish Society for Town and Country Planning.

[16] Eriksson, L., Nordlund, A. M., Olsson, O. \& Westin, K. (2012a). Recreation in different forest settings: A scene preference study. Forests 3(4), 923-943. DOI: 10.3390/f3040923.

[17] Eriksson, L., Nordlund, A. M., Olsson, O. \& Westin K. (2012b). Beliefs about urban fringe forests among urban residents in Sweden. Urban Forestry and Urban Greening, 11(3), 321328. DOI: 10.1016/j.ufug.2012.02.004.

[18] Folke, C., Hahn, T., Olsson, P. \& Norberg, J. (2005). Adaptive governance of socialecological systems. Annual Review of Environment and Resources 30, 441-473. DOI: 10.1146/annurev.energy.30.050504.144511.

[19] Friedmann, J. \& Weaver, C. (1979). Territory and Function - The Evolution of Regional Planning. London: Edward Arnold.

[20] Fries, C., Carlsson, M., Dahlin, B., Lämås, T. \& Sallnäs, O. (1998). A review of conceptual landscape planning models for multiobjective forestry in Sweden. Canadian journal of forest research, 28(2), 159-167. DOI: 10.1139/x97-204.

[21] Galland, D. (2012a). Understanding the reorientations and roles of spatial planning: The case of national planning policy in Denmark. European Planning Studies 20(8), 1359-1392. DOI: $10.1080 / 09654313.2012 .680584$.

[22] Galland, D. (2012b). Is regional planning dead or just coping? The transformation of a state sociospatial project into growth-oriented strategies. Environment and Planning $C$ : Government and Policy 30(3), 536-552. DOI: 10.1068/c11150.

[23] Galland, D. \& Hansen, C. J. (2012). The roles of planning in waterfront redevelopment: From plan-led and market-driven styles to hybrid planning? Planning Practice and Research 27(2), 203-225. DOI: 10.1080/02697459.2012.661669.

[24] Gardner, R., Ostrom, E. \& Walker, J. M. (1990). The nature of common-pool resource problems. Rationality and Society 2(3), 335-358. DOI: 10.1177/1043463190002003005.

[25] Gislerud, O. \& Neven, I., eds. (2002). National forest programmes in a European context. EFl proceedings No 44. Joensuu: European Forest Institute.

[26] Gunton, T. (2003). Natural Resources and Regional Development: An Assessment of Dependency and Comparative Advantage Paradigms. Economic Geography 79(1), 67-94. DOI: $10.1111 / \mathrm{j} .1944-8287.2003 . \mathrm{tb} 00202 . x$.

[27] Haughton, G., Allmendinger, P., Counsell, D. \& Vigar, G. (2009). The new spatial planning: Territorial management with soft spaces and fuzzy boundaries. London: Routledge.

[28] Innis, H. A. (1956). The fur trade in Canada, An Introduction to Canadian Economic History. Toronto: University of Toronto Press. 
[29] Johansson, J. (2016). Participation and deliberation in Swedish forest governance: The process of initiating a National Forest Program. Forest Policy and Economics 70, 137146. DOI: 10.1016/j.forpol.2016.06.001.

[30] Johnson, G. (2013). Regional planning in Sweden. In Lundström, M. J., Fredriksson, C. \& Witzell, J., eds., Planning in Sweden (pp. 97-109). Stockholm: Swedish Society for Town and Country Planning.

[31] Kangas, A., Saarinen, N., Saarikoski, H., Leskinen, L. A., Hujala, T. \& Tikkanen, J. (2010). Stakeholder perspectives about proper participation for Regional Forest Programmes in Finland. Forest Policy and Economics 12(3), 213-222. DOI: 10.1016/j.forpol.2009.10.006.

[32] Keskitalo, E. C. H. (2004). A framework for multi-level stakeholder studies in response to global change. Local Environment 9(5), 425-435. DOI: 10.1080/1354983042000255333.

[33] Keskitalo, E. C. H., Baird, J., Ambjörnsson, E. L. \& Plummer, R. (2014). Social network analysis of multi-level linkages: A Swedish case study on northern forest-based sectors. Ambio 43(6), 745-758. DOI: 10.1007/s13280-014-0492-0.

[34] Lawrence, A. (2009). Forestry in transition: Imperial legacy and negotiated expertise in Romania and Poland. Forest Policy and Economics 11(5-6), 429-436. DOI: 10.1016/j.forpol.2009.02.003.

[35] Leskinen, L. (2004). Purposes and challenges of public participation in regional and local forestry in Finland. Forest Policy and Economics 6(6), 605-618. DOI: 10.1016/S13899341(03)00009-1.

[36] Mackintosh, W. A. (1964). The economic background of dominion-provincial relations. Toronto: McClelland and Stewart.

[37] Montiela, C. \& Galiana, L. (2005). Forest policy and land planning policy in Spain: a regional approach. Forest Policy and Economics 7(2), 131-142. DOI: 10.1016/S13899341(03)00026-1.

[38] Myrdal, G. (1957). Economic Theory and Underdeveloped Regions. London: Duckworth.

[39] Nyström, J. \& Tonell, L. (2012). Planeringens grunder - en översikt. 3rd ed. Lund: Studentlitteratur.

[40] Olesen, K. (2013). The neoliberalisation of strategic spatial planning. Planning Theory, 13(3), 288-303. DOI: 10.1177/1473095213499340.

[41] Saarikoski, H., Åkerman, M. \& Primmer, E. (2012). The challenge of governance in regional forest planning: An analysis of participatory forest program processes in Finland. Society and Natural Resources 25(7), 667-682. DOI: 10.1080/08941920.2011.630061.

[42] Sandström, P., Sandström, C., Svensson, J., Jougda, L. \& Baer, K. (2012). Participatory GIS to mitigate conflicts between reindeer husbandry and forestry in Vilhelmina Model Forest, Sweden. The Forestry Chronicle 88(3), 254-260. DOI: 10.5558/tfc2012-051.

[43] Stjernström, O., Karlsson, S. \& Pettersson, Ö. (2013). Skogen och den kommunala planeringen. PLAN, 2013(1), 42-45.

[44] Stjernström, O., Ahas, R., Bergstén, S., Eggers, J., Hain, H., Karlsson, S., Keskiltalo E. C. H., Lämås, T., Pettersson, Ö., Sandström, P. \& Öhman, K. (2017). Multi-level Planning and Conflicting Interests in the Forest Landscape, in Keskiltao, E. C. H. (ed.), Globalisation and Change in Forest Ownership and Forest Use. London: Palgrave Macmillan.

[45] Tikkanen, J. (2017). Participatory turn - and down-turn - in Finland's regional forest programme process. Forest Policy and Economics (in press). DOI: 10.1016/j.forpol.2017.04.009.

[46] Tittler, R., Messier, C. \& Burton, P. J. (2001). Hierarchical forest management planning and sustainable forest management in the boreal forest. The Forestry Chronicle 77(6), 998-1005. DOI: $10.5558 / \mathrm{tfc} 77998-6$. 
[47] Weber, N. (2017). Participation or involvement? Development of forest strategies on national and sub-national level in Germany. Forest Policy and Economics (in press). DOI: 10.1016/j.forpol.2017.04.002.

[48] Zaremba, M. (2012). Skogen vi ärvde. Stockholm: Weyler förlag.

\section{Other sources}

[49] Finlands skogscentral (2016). Österbottens skogsprogram 2016-2020. Finlands skogscentral.

[50] SFS 1998:808 Miljöbalk (Environemental Code).

[51] SFS 2010:900 Plan- och bygglag (Planning and Building Act).

[52] SFS 1979:429 Skogsvårdslag (Forestry Act).

[53] SOU 1971:75 Hushållning med mark och vatten.

[54] SOU 1979:54 Hushållning med mark och vatten.

[55] SOU 2012:81 Statens regionala förvaltning, förslag till en angelägen reform.

[56] Swedish Forest Agency (2012). Swedish Statistical Yearbook of Forestry 2012. Jönköping.

[57] Swedish Forest Agency (2016):

http://www.skogsstyrelsen.se/Aga-och-bruka/Skogsbruk/Aga-skog/Skogsbruksplan/. 